\title{
Metabolism of nitrogenous compounds in the large intestine of sheep
}

\author{
BY J. F. HECKER* \\ Department of Veterinary Clinical Studies, School of Veterinary Medicine, \\ Madingley Road, Cambridge
}

(Received I9 February 1970-Accepted $17 \mathcal{F u l y}$ 1970)

\begin{abstract}
I. The deamination, ureolytic and proteolytic activities and rates of cellulolysis and gas production in large intestinal contents have been compared with those activities and rates in rumen contents of sheep.

2. Large intestinal contents produced ammonia. The rate of ammonia production was greater in caecal contents than in faeces. Incubation of caecal contents under toluene resulted in decreased production of ammonia and volatile fatty acids and an increase in the concentration of $\alpha$-amino nitrogen.

3. Proteolytic activity of large intestinal contents was much greater than that of rumen contents. There was little difference in proteolytic activity between caecal or faecal contents and their liquors whereas the activity in rumen whole contents was greater than in rumen liquor. Some proteolytic activity was present in caecal and faecal cell-free liquors but none was present in rumen cell-free liquor.

4. Deaminase activity was greater in rumen than in caecal contents or faeces. The activity in rumen liquor was less than half that in rumen whole contents.

5. Urease activity of caecal contents was less than that of faeces or of rumen contents.

6. The rate of gas production in rumen contents was less than that in caecal contents. The rate in faeces was low. Less gas was produced in rumen liquor than in rumen contents, whereas there was little difference between rates in caecal liquor and whole contents.

7. Rates of breakdown of cellulose in vivo were similar in the rumen and the caecum.
\end{abstract}

The large intestine of the ruminant as a digestive organ has been little studied compared with the rumen. Microbial digestion in the large intestine appears to be similar to that in the rumen, the principal difference between the digestive processes in the two organs being due to the fact that, since the hydrolytic digestion of proteins, starches, sugars and fats occurs before the digesta reaches the caecum, the amounts of these substances that reach the caecum are likely to be small or negligible.

The fate of proteins in the large intestine is particularly intriguing since the contents of plant cells could reach the caecum intact and since mucus and other compounds enter the intestine (Phillipson, 1964). The work reported here was an investigation into certain enzymatic activities of the contents of the large intestine of sheep. The activities have been compared with those of the rumen contents to determine whether the digestive capacities of the two organs are similar for proteins and protein derivatives.

\section{EXPERIMENTAL}

\section{Animals and feeding}

Four Clun Forest ewes or wethers of at least I year of age were used. Each had a rumen and a caecal cannula. They were kept in pens and allowed free access to water,

* Present address: Department of Physiology, University of New England, Armidale, NSW, Australia. 
salt licks and, unless specifically stated to the contrary, meadow hay in hay nets. Sufficient hay was placed in the nets to ensure that there was always some remaining. Each morning, this was removed and replaced with fresh hay. During one period of $\mathrm{I} 2 \mathrm{~d}$, hay was replaced for one sheep by barley straw ( $0.25 \%$ nitrogen). During a further period of $16 \mathrm{~d}$, this sheep was given a concentrate supplement consisting mainly of crushed oats, barley and maize meal (2.8\% nitrogen) and then the same diet supplemented with $20 \mathrm{~g}$ urea for a further $10 \mathrm{~d}$.

\section{Sampling and preparation of liquors}

The whole contents from either the rumen or the large intestine or the liquors obtained from these contents were examined. Samples in the various experiments were taken over a period of several months and no more than one sample was taken from an organ per day. Rumen fluid and caecal contents were obtained by suction into tubes of internal diameter 6-10 $\mathrm{mm}$. Rumen contents were also removed by inserting a pair of long-nosed forceps through the cannula and withdrawing material that was trapped between the jaws. Some $20 \mathrm{~g}$ of material were obtained with three or four such removals. This material is referred to here as whole rumen contents. Faeces were collected during normal defaecation or were removed from the rectum.

Liquors were obtained by squeezing caecal contents or a faecal slurry produced by macerating faeces with 3 parts by weight of phosphate buffer $(0.2 \mathrm{M}, \mathrm{pH} 7 \cdot 0$; Long, I96I) in an Atomix blender (Measuring and Scientific Equipment Ltd, London) or by straining rumen fluid through one layer of surgical gauze. Results for faecal liquor were corrected for the initial dilution with buffer. Samples were used as soon as possible after collection. Except for samples used for estimation of the rate of proteolysis, liquors were run under $\mathrm{I} \mathrm{cm}$ of liquid paraffin and whole contents were placed in containers, filled to the brim and then stoppered in order to reduce loss of carbon dioxide.

\section{Analytical methods}

Urea and ammonia were measured by micro-diffusion analysis (Conway, r957) without prior deproteinization.

Volatile fatty acid measurements were made with a Beckman GC-2A Gas Chromatogram. Precipitation of protein from caecal liquor was obtained by addition of 0.2 vol. of $25 \%$ (w/v) metaphosphoric acid (Erwin, Marco \& Emery, r96r) followed by centrifugation.

The nitrous oxide method of Peters \& Van Slyke (1932) was used to estimate soluble $\alpha$-amino nitrogen. The samples were prepared by precipitating protein by the addition of 4 vol. ethanol and drying at $37^{\circ}$ the supernatant fluid obtained by centrifugation. The deposit was dissolved in a known volume of water and any material that did not dissolve was deposited by centrifugation. This procedure removed all ammonia.

\section{Enzyme assays}

Proteolytic activity. Proteolytic activity was measured by a method similar to that described by Blackburn \& Hobson (1960) which estimates the rate of breakdown of casein incubated under toluene to prevent microbial multiplication. Normally, 4 vol. 
of $3 \%$ (w/v) casein (light, white, soluble), 4 vol. of $0.2 \mathrm{M}$-phosphate buffer $(\mathrm{pH} 7 \cdot 0)$, I vol. of $0.6 \%(\mathrm{w} / \mathrm{v}) \mathrm{L}$-cysteine and I vol. of inoculum were incubated at $37^{\circ}$. Controls were incubated with an equal volume of water replacing the casein, and sometimes with water replacing the inoculum. In the latter, no changes in casein concentration were observed. In a few estimations gelatin, fibrin or gluten were substituted for casein. Samples were taken from the incubation mixtures at the start of incubation and after a period, which was usually $6 \mathrm{~h}$ for caecal and faecal liquors and whole contents and $24 \mathrm{~h}$ for rumen liquor and whole rumen contents. Protein in these samples was precipitated by adding 4 vol. of $10 \%(\mathrm{w} / \mathrm{v})$ trichloroacetic acid, depositing the precipitate by centrifugation, decanting the supernatant liquid and dissolving the precipitate in $2 \mathrm{ml}$ of $\mathrm{I} \mathrm{N}$-sodium hydroxide. Biuret reagent (Reinhold, 1953) was added to the supernatant fluid, and, after insoluble material had been deposited by centrifugation, the extinction was measured at $55^{\circ} \mathrm{nm}$ in a Unicam SP 600 spectrophotometer. Rumen whole contents were agitated gently with a magnetic stirrer as it was noticed that the larger plant particles settled to the bottom. No settling of particles was noticed with caecal or faecal whole contents or with liquors.

Preliminary measurements indicated that casein disappeared more rapidly from caecal than from rumen liquor. Rumen liquor required incubation for $24 \mathrm{~h}$ to allow $20-80 \%$ of the casein to disappear, whereas caecal and faecal liquors required considerably less time for a similar disappearance. Measurements of casein and gelatin concentrations in samples taken at different times during incubation with rumen or caecal liquors showed that the concentrations decreased in a curvilinear manner with time. When concentrations were plotted on semi-logarithmic graph paper against time, straight lines resulted, indicating that proteolysis observed first-order enzyme kinetics. To allow comparisons to be made between different incubation times, the half-lives of the substrates were calculated. Results are expressed as units of proteolytic activity to enable statistical tests to be performed. These units have been calculated as the reciprocals of the half-lives.

Deaminase and urease activities. Deaminase activity was assayed by measuring the ammonia produced when I vol. of inoculum was incubated at $37^{\circ}$ with $\mathrm{I}$ vol. of $4 \%(\mathrm{w} / \mathrm{v})$ casein hydrolysate (casein hydrolysate for bacteriological use; British Drug Houses Ltd, Poole, Dorset) under $\mathrm{r} \mathrm{cm}$ of liquid paraffin. The method for urease was similar except that $x$ vol. of a $6 \%$ (w/v) urea solution was added to the inoculum. Ammonia concentrations at the end of incubation were corrected for the initial ammonia concentrations and for changes in ammonia concentration in controls diluted with I vol. of water. When whole contents were used, dilution with casein hydrolysate, urea solutions or with water was by weight. Preliminary measurements showed that the amount of ammonia produced was proportional to the length of the incubation period. Periods of $120 \mathrm{~min}$ and $10 \mathrm{~min}$ were used for assay of deaminase and urease activities respectively.

Cellulolysis. The rate of cellulolysis was measured by the method of Grosskopf (1964). Cotton threads, $100 \mathrm{~cm}$ long of approximately $100 \mathrm{mg}$ weight, were thoroughly washed, dried and weighed. They were tied in a loop with a piece of nylon thread 
and suspended singly through the rumen or caecal cannula of one sheep for periods of up to $80 \mathrm{~h}$. At the end of this period, they were removed, washed thoroughly and dried and their losses of weight were determined. Their lengths were measured and any values shorter than $100 \mathrm{~cm}$ were discarded.

Fermentation rate. This was estimated as the rate of production of gas, measured in standard Warburg manometric apparatus using mercury-filled manometers. Between 2 and $4 \mathrm{~g}$ of liquor or whole contents were placed in each flask which was then flushed for Io min with carbon dioxide and incubated at $37^{\circ}$. Faecal pellets when placed in the flasks were crushed lightly with a glass rod. Manometer readings were made at $5 \mathrm{~min}$ intervals for $50 \mathrm{~min}$ after an initial period of about $15 \mathrm{~min}$ for equilibration. From these readings, results were calculated as $\mu 1$ carbon dioxide liberated per $5 \mathrm{~min}$ by $100 \mathrm{~g}$ of liquor or contents (Umbreit, Burris \& Stauffer, I95 I).

Hungate, Phillips, Hungate \& MacGregor (1960), in a similar method, added sodium bicarbonate to their flasks. Some $10 \%(\mathrm{w} / \mathrm{v})$ sodium bicarbonate (1 or $2 \mathrm{ml}$ ) was added to a few flasks in these experiments. This did not affect the rate of carbon dioxide evolution from caecal liquor but increased it slightly from rumen liquor and markedly from faeces. This increase from faeces was not seen when the same volume of water was added to the flasks. As the addition of bicarbonate resulted in a rise in $\mathrm{pH}$, results from these flasks were ignored.

\section{RESULTS}

\section{Production of ammonia}

In caecal liquor. Ammonia was present in all the samples of caecal liquor that were analysed. When samples were taken at different times during the day and incubated under liquid paraffin at $37^{\circ}$, an increase in concentration of ammonia always occurred. The rate of production of ammonia tended to decrease slightly when caecal liquor was incubated for periods greater than $90 \mathrm{~min}$. The rate did not vary significantly with $\operatorname{diet}$ (Table I).

Table 1. Ammonia produced in caecal liquor incubated at $37^{\circ}$ for 90 min; the sheep was given four diets

(Mean values with their standard errors)

\begin{tabular}{|c|c|c|}
\hline Diet & $\begin{array}{c}\text { No. of } \\
\text { samples }\end{array}$ & $\begin{array}{c}\text { Ammonia-N } \\
\text { produced } \\
(\mathrm{mg} / 100 \mathrm{~g})\end{array}$ \\
\hline Straw & 5 & $4.1 \pm 0.6$ \\
\hline Hay & 7 & $3.3 \pm 0.3$ \\
\hline Hay + concentrates & 6 & $4.2 \pm 0.4$ \\
\hline Hay + urea + concentrates & 6 & $3.2 \pm 0.3$ \\
\hline Mean & 24 & $\begin{array}{r}3.8 \pm 0.2 \\
0.93\end{array}$ \\
\hline
\end{tabular}

NS, not significant (analysis of variance).

In whole caecal contents. A comparison was made between the rate of increase in ammonia concentration in caecal liquor and whole contents incubated at $37^{\circ}$. The mean increase in the whole contents of twelve samples was $4.9 \pm 0.8$ (SE) mg ammonia- 
$\mathrm{N} / \mathrm{lo0} \mathrm{g}$, whereas the value for liquor from the same samples was $5.2 \pm 0.8 \mathrm{mg}$. The difference was not significant $(t=\mathrm{I} \cdot 23)$.

In faeces. The results for measurements on ten samples of faecal pellets and on the twelve samples of whole caecal contents referred to above are given in Table 2. The production of ammonia from faeces was less than half that formed from caecal contents on a wet-matter basis, and approximately one-eighth of that from caecal contents when compared on a dry-matter basis.

Table 2. Ammonia concentration and production of ammonia in caecal contents and faeces of sheep when incubated for 90 min at $37^{\circ}$

\begin{tabular}{|c|c|c|c|c|c|}
\hline & & Mean values & their standard & ors) & \\
\hline & & & Initial & Increase & nmonia-N \\
\hline & $\begin{array}{l}\text { No. of } \\
\text { samples }\end{array}$ & $\begin{array}{c}\text { Dry matter } \\
(\%)\end{array}$ & $\begin{array}{c}\text { concentration } \\
(\mathrm{mg} / \mathrm{r} 00 \mathrm{~g})\end{array}$ & $\begin{array}{c}(\mathrm{mg} / \mathrm{r} 00 \mathrm{~g}) \\
\text { (wet matter) }\end{array}$ & $\begin{array}{l}\text { (mg/roog) } \\
\text { (dry matter) }\end{array}$ \\
\hline Caecal contents & 12 & $1 I \cdot 2 \pm 0 \cdot 2$ & $27 \cdot 1 \pm 2 \cdot 2$ & $4.9 \pm 0.8$ & $44 \cdot 0 \pm 7 \cdot 0$ \\
\hline Faeces & Io & $35 \cdot 3 \pm 1 \cdot 0$ & $10.0 \pm 1.0$ & $1.9 \pm 0.3$ & $5.5 \pm 0.8$ \\
\hline
\end{tabular}

Table 3. Concentration of ammonia, $\alpha$-amino nitrogen and volatile fatty acids ( $m$-moles $/ l$ ) in caecal liquor of sheep incubated under toluene and under liquid paraffin at $37^{\circ}$

(Mean values for three experiments)

\begin{tabular}{|c|c|c|c|c|c|c|c|c|}
\hline & Ammonia & $\alpha-\mathrm{NH}_{2}-\mathrm{N}$ & $\begin{array}{l}\text { Acetic } \\
\text { acid }\end{array}$ & $\begin{array}{l}\text { Pro- } \\
\text { pionic } \\
\text { acid }\end{array}$ & $\begin{array}{c}\text { Butyric } \\
\text { acid }\end{array}$ & $\begin{array}{l}\text { Valeric } \\
\text { acid }\end{array}$ & $\begin{array}{l}\text { Iso- } \\
\text { valeric } \\
\text { acid }\end{array}$ & $\begin{array}{l}\text { Total } \\
\text { VFA }\end{array}$ \\
\hline At start of incubation & I. 43 & 0.16 & 4.55 & 0.83 & 0.27 & 0.06 & 0.04 & $5 \cdot 75$ \\
\hline Under paraffin for $\mathrm{I} h$ & $\mathrm{I} \cdot 83$ & 0.15 & 5.01 & 0.95 & 0.32 & 0.07 & 0.06 & $6 \cdot 41$ \\
\hline Under paraffin for $2 \mathrm{~h}$ & I.97 & 0.12 & $5 \cdot 30$ & I.OI & 0.33 & 0.08 & 0.06 & $6 \cdot 77$ \\
\hline Under toluene for $\mathrm{th}$ & $x \cdot 60$ & 0.20 & $4 \cdot 48$ & $0.8 \mathrm{I}$ & 0.27 & 0.05 & 0.04 & $5 \cdot 65$ \\
\hline Under toluene for $2 \mathrm{~h}$ & $I \cdot 66$ & 0.30 & 4.42 & 0.80 & 0.27 & 0.05 & $0 \cdot 03$ & $5 \cdot 57$ \\
\hline
\end{tabular}

Effect of incubation under toluene. When caecal liquor was incubated under toluene, the increase in ammonia was less than under liquid paraffin, and in several samples no change in ammonia concentration was seen. The mean increase in six samples during $90 \mathrm{~min}$ under liquid paraffin was $3.4 \pm 0.2 \mathrm{mg}$ ammonia-N/100 g, whereas under toluene it was $0.9 \pm 0.4 \mathrm{mg}$. In five other samples, the respective increases were $4.6 \pm 0.9$ and $\mathrm{I} \cdot 5 \pm 0.6$ at $60 \mathrm{~min}$ and $6 \cdot 2 \pm \mathrm{I} \cdot 2$ and $2 \cdot 2 \pm 0.8$ at $\mathrm{I} 20 \mathrm{~min}$. As Warner (I956) showed that toluene inhibited the deamination of amino acids by rumen bacteria, the decrease in ammonia production which resulted when incubation was done under toluene suggested that this ammonia was produced by deamination of amino acids.

To confirm this suggestion, portions of three samples of caecal liquor were incubated under liquid paraffin or toluene at $37^{\circ}$, and ammonia, $\alpha$-amino nitrogen and volatile fatty acid concentrations were measured in subsamples taken at $0, \mathrm{I}$ and $2 \mathrm{~h}$. The results are given in Table 3 . Under liquid paraffin, there were increases in concentrations of ammonia and volatile fatty acids and a slight decrease in $\alpha$-amino nitrogen. Under toluene, the increase in ammonia was less; there was a decrease in the concentration of volatile fatty acids, and an increase in the concentration of 
$\alpha$-amino nitrogen. The difference between the concentrations of $\alpha$-amino nitrogen at $2 \mathrm{~h}$ under paraffin and under toluene $(0.18 \mathrm{~m}$-moles $/ \mathrm{l})$ was less than that for ammonia $(0 \cdot 3 \mathrm{I} \mathrm{m}$-moles $/ 1)$ but much less than that for volatile fatty acids $(\mathrm{I} \cdot 2 \mathrm{~m}$-moles $/ \mathrm{l})$.

\section{Proteolytic activity}

In liquor. The mean proteolytic activity in thirty-five samples of rumen liquor $(0.022 \pm 0.003$ units) was much less than the mean activities in forty samples of caecal liquor ( $0.3^{6} \pm 0.05$ units) and in seventeen samples of faecal liquor (0.60 \pm 0.10 units). The differences in activity between rumen and caecal, rumen and faecal, and caecal and faecal liquors were all significant $(P<0.01,0.01,0.05)$.

The percentages of gelatin, fibrin, gluten and casein remaining after incubation with two samples of rumen and of caecal liquors are given in Table 4. With both rumen and caecal liquors, gelatin was hydrolysed more rapidly and fibrin and gluten less rapidly than casein. Breakdown of each substrate in a given time was greater in caecal than in rumen liquor.

Table 4. Proteolysis of gelatin, casein, fibrin and gluten in two samples of rumen and two samples of caecal liquor obtained from sheep

\begin{tabular}{|c|c|c|c|}
\hline & \multirow{2}{*}{$\begin{array}{c}\text { Time of } \\
\text { incubation } \\
\text { (h) }\end{array}$} & \multicolumn{2}{|c|}{$\%$ remaining at end of incubation } \\
\hline & & Rumen liquor & Caecal liquor \\
\hline Gelatin & 0.5 & $\begin{array}{l}79.9 \\
84.0\end{array}$ & $\begin{array}{l}39 \cdot 5 \\
34 \cdot 3\end{array}$ \\
\hline Casein & 4 & $\begin{array}{l}77 \cdot 5 \\
89 \cdot 0\end{array}$ & $\begin{array}{l}16 \cdot 6 \\
66 \cdot 0\end{array}$ \\
\hline Fibrin & 24 & $\begin{array}{l}8 x \cdot 5 \\
74 \cdot 8\end{array}$ & $\begin{array}{l}69 \cdot 5 \\
37 \cdot 8\end{array}$ \\
\hline Gluten & 24 & $\begin{array}{l}72 \cdot 0 \\
49 \cdot 1\end{array}$ & $\begin{array}{l}58 \cdot 8 \\
25 \cdot 8\end{array}$ \\
\hline
\end{tabular}

Table 5. Proteolytic activity in cell-free and cellular fractions of rumen, caecal and faecal liquors obtained from sheep

(Mean values with their standard errors)

\begin{tabular}{|c|c|c|c|c|}
\hline \multirow[b]{2}{*}{ Site } & \multirow{2}{*}{$\begin{array}{l}\text { No. of } \\
\text { samples }\end{array}$} & \multicolumn{3}{|c|}{ Proteolytic activity (units)* } \\
\hline & & Cell-free† & Cellular $\ddagger$ & Total \\
\hline Rumen & 3 & $\circ$ & $0.017 \pm 0.003$ & $0.017 \pm 0.003$ \\
\hline Caecum & 8 & $0.072 \pm 0.010$ & $0.34 \pm 0.04$ & $0.42 \pm 0.07$ \\
\hline Faeces & 6 & $0.130 \pm 0.033$ & $0.49 \pm 0.20$ & $0.62 \pm 0.20$ \\
\hline
\end{tabular}

In cell-free liquor. Estimations of proteolytic activity were made on several samples of rumen, caecal and faecal liquors and on the supernatant fluids obtained from these liquors after high-speed centrifugation $(14800 \mathrm{~g}$ ). The proteolytic activity associated with the particulate matter in the liquors was calculated from the difference. Results 
are given in Table 5 . No proteolysis occurred in cell-free rumen liquor. However, in cell-free caecal and faecal liquors, considerable proteolytic activity was found, but this was usually less than that associated with the particulate matter.

Effect of $\mathrm{pH}$. Measurements of $\mathrm{pH}$ of ten samples of rumen liquor made within $5 \mathrm{~min}$ of sampling averaged $6.73 \pm 0.04$ whereas the average $\mathrm{pH}$ of ten samples of caecal liquor was $7 \cdot 24 \pm 0 \cdot 05$. These values differed from $\mathrm{pH} 7 \cdot 0$ at which the rate of proteolysis was measured and this might have accounted for the difference in activity found between rumen and caecal liquors. To determine the effect of $\mathrm{pH}$ on proteolysis, proteolytic activity was estimated in the presence of varying proportions of $\mathrm{Na}_{2} \mathrm{HPO}_{4}$
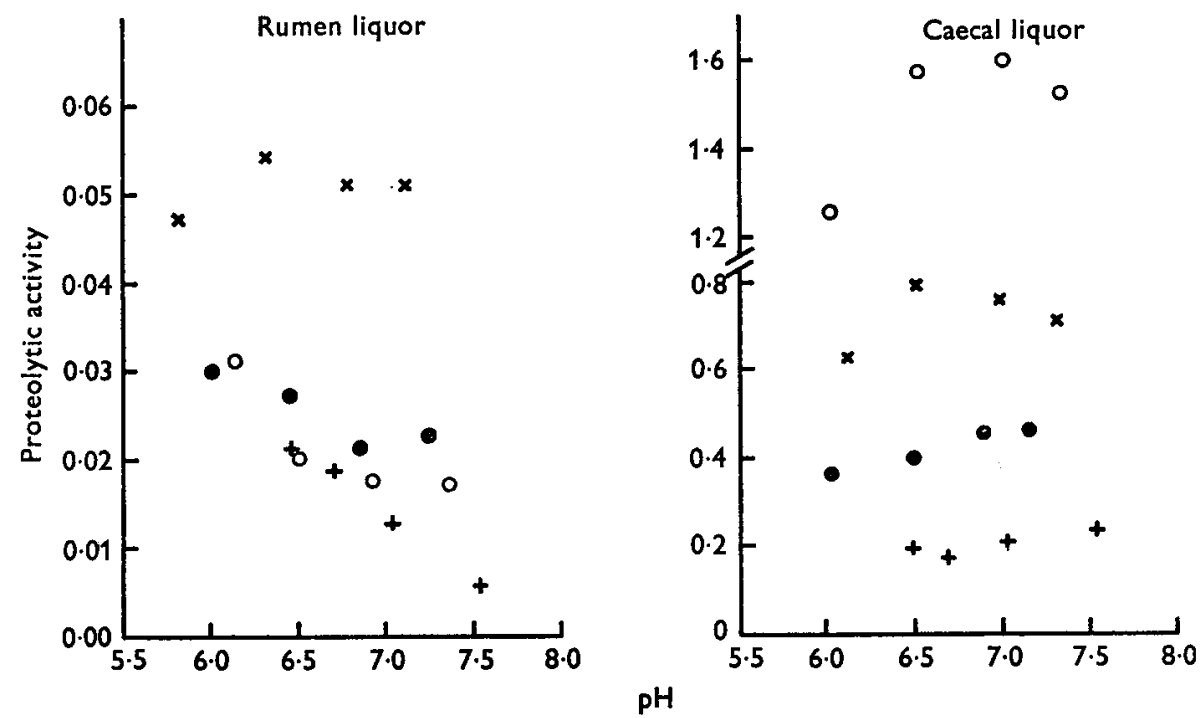

Fig. 1. Effect of $\mathrm{pH}$ on proteolytic activity in rumen and caecal liquors of sheep in four $(x+0)$ different experiments.

Table 6. Proteolytic activity in gastro-intestinal contents and liquors obtained from sheep

(Mean values with their standard errors for five determinations)

\begin{tabular}{lccc} 
& \multicolumn{4}{c}{ Proteolytic activity (units) } \\
Site & Whole contents & Liquor & $t$ \\
Rumen & $0.08 \mathrm{I} \pm 0.005$ & $0.027 \pm 0.004$ & $7.2^{* *}$ \\
Caecum & $0.59 \pm 0.1 \mathrm{I}$ & $0.67 \pm 0.14$ & $2.13^{\mathrm{NS}}$ \\
Faeces & $0.92 \pm 0.18$ & $0.87 \pm 0.16$ & $0.45^{\mathrm{NS}}$ \\
& NS, not significant (paired $t$ test). \\
& $* * P<0.0$ (paired $t$ test). \\
& $\dagger$ See p. 87.
\end{tabular}

and $\mathrm{KH}_{2} \mathrm{PO}_{4}$ with a phosphate concentration of $0.2 \mathrm{M}$ and a $\mathrm{pH}$ which varied between 6.0 and 7.5 . The results of four incubations with rumen and caecal liquors are shown in Fig. $\mathrm{r}$. The $\mathrm{pH}$ optima appeared to be higher in caecal than in rumen liquor. This 
difference, however, would not account for the large difference in proteolytic activity between the two liquors when incubation was done at $\mathrm{pH} 7 \cdot 0$.

Whole contents. The results of several measurements which were made to compare proteolytic activity in whole contents and liquor are given in Table 6. Differences between the faecal whole contents and liquor and between caecal contents and liquor were not significant. However, the results showed a more rapid rate of proteolysis in rumen whole contents than in the liquor.

\section{Deamination}

The rate of production of ammonia from casein hydrolysate (Table 7) was greater with faecal than with rumen or caecal contents. However, the differences were not significant. In another five samples of rumen contents, liquor had significantly less activity than did whole contents ( $18 \cdot 0 \pm \mathrm{I}^{\circ} 3$ as compared with $43 \cdot 3 \pm 2 \cdot 5 \mathrm{mg}$ ammonia-N released per I00 $\mathrm{g} ; P<0.0 \mathrm{I})$.

\section{Urease activity}

Urease activity was greater in rumen contents than in caecal contents and approximately four times greater in faeces than in caecal contents (Table 7). The differences in activity between rumen and caecal, rumen and faecal, and caecal and faecal contents were significant $(P<0.05,0.01,0.01)$.

Table 7. Urease activity and deaminase activity in gastro-intestinal contents from a sheep

(Mean values with their standard errors for five determinations)

$\begin{array}{lcc}\text { Contents } & \begin{array}{c}\text { Urease activity } \\ \text { (mg ammonia-N } \\ \text { produced per } \\ \text { Ioog digesta) }\end{array} & \begin{array}{c}\text { Deaminase activity } \\ \text { (mg ammonia-N } \\ \text { produced per } \\ \text { roog digesta) }\end{array} \\ \text { Rumen } & 32 \cdot \mathrm{I} \pm \mathrm{I} \cdot 4 & 26 \cdot 5 \pm 3 \cdot 9 \\ \text { Caecum } & 19 \cdot 4 \pm \mathrm{I} \cdot 3 & 29 \cdot 8 \pm 6 \cdot 2 \\ \text { Faeces } & 82 \cdot 8 \pm 5 \cdot 4 & 34 \cdot 4 \pm 7 \cdot 9\end{array}$

Table 8. Gas production in gastro-intestinal contents of sheep

(Mean values with their standard errors for five determinations)

\begin{tabular}{lccc}
\multicolumn{1}{c}{ Site } & $\begin{array}{c}\text { Whole contents } \\
(\mu 1 / \text { roog } 5 \mathrm{~min})\end{array}$ & $\begin{array}{c}\text { Liquor } \\
(\mu 1 / \text { roo g } 5 \mathrm{~min})\end{array}$ & $t$ \\
Rumen & $218 \pm 43$ & $72 \pm \mathrm{Ir}$ & $28 * * *$ \\
Caecum & $160 \pm 25$ & $155 \pm 30$ & $0.79^{\mathrm{NS}}$ \\
Faeces & $23 \pm 4$ & $\mathrm{ND}$ & \\
& & \\
& $\mathrm{ND}$, not determined. & \\
& $\mathrm{NS}$, not significant (paired $t$ test). \\
& $* * * P<0.00$ (paired $t$ test).
\end{tabular}

\section{Fermentation rate}

The production of gas from rumen contents was slightly greater than from caecal contents, and gas production from faeces was small (Table 8). Less gas was produced from rumen liquor than from rumen whole contents, but there was no significant 
difference between production from caecal liquor and whole caecal contents. The difference between rumen and caecal contents was not significant, whereas the difference between either rumen or caecal contents and faeces was significant $(P<0.01)$.

\section{Cellulolysis}

The rates of breakdown of cotton threads suspended in the rumen and the caecum were similar (Fig. 2). There appeared to be an initial period of approximately $20 \mathrm{~h}$ when little or no breakdown occurred. The time for half the weight of the threads to be digested was between 50 and $70 \mathrm{~h}$.

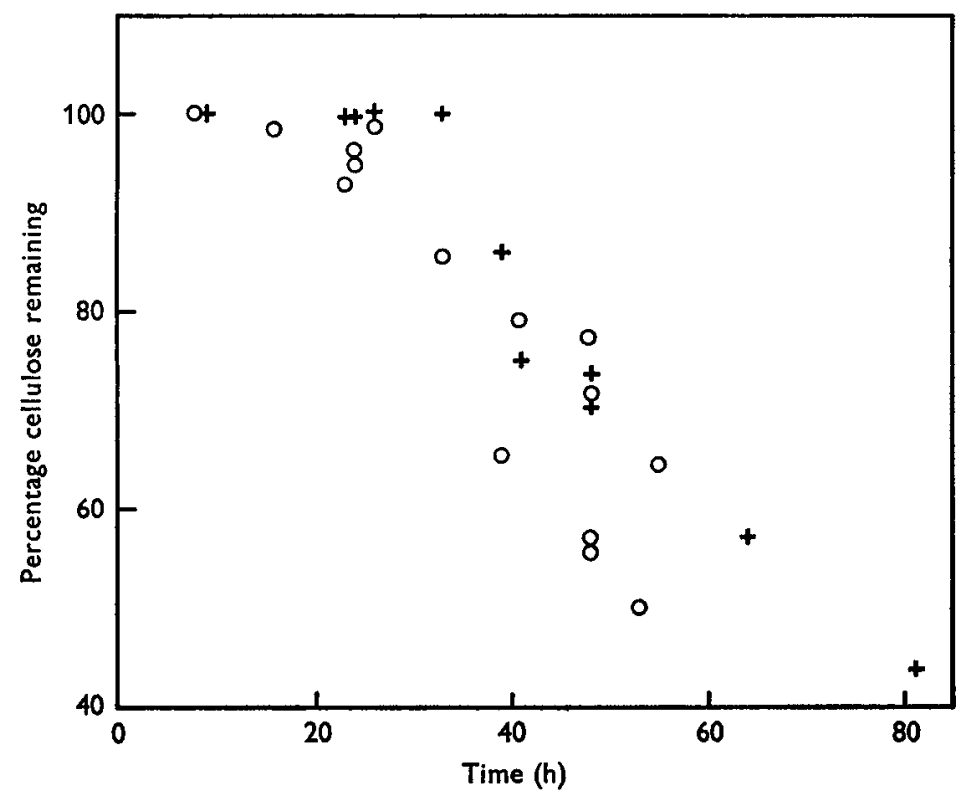

Fig. 2. Breakdown of cellulose in the rumen $(+)$ and the caecum $(O)$ of sheep.

\section{DISCUSSION}

In the comparisons made between whole contents and liquors, rumen liquor had lower proteolytic and deaminase activities and a lower rate of gas production than whole rumen contents. The difference was due probably to a reduction in numbers of bacteria and protozoa when the liquor was strained through gauze to remove the larger plant particles (Warner, I962). The absence of protozoa from caecal contents of sheep and the smaller number of organisms attached to food particles (Baker, 1939) may explain why there was little difference between activities in caecal liquor and caecal whole contents.

Except for proteolysis, the activity of caecal whole contents was of an order of magnitude similar to that of rumen whole contents. Few comparisons have been made between rumen and caecal contents. Brüggemann \& Giesecke (1963) found that the rate of breakdown of cellulose was more rapid in rumen than in caecal contents obtained from cattle. Spravcev ( 1963 ) observed greater rates of cellulolysis in caecal 
than in rumen contents of sheep. Begovic \& Pavlić (1967) found the rate of reduction of nitrate to be less in caecal than in rumen contents of slaughtered cattle, while cellulolysis and the fermentation of glucose were more rapid in caecal than in rumen contents. Hungate, Phillips, McGregor, Hungate \& Buechner (1959) observed greater fermentation rates in the rumen than in the large intestinal contents of several African herbivores. The measurement of the rate of fermentation by the last authors was made after the addition of bicarbonate to the flasks (Hungate et al. 1960) and their results may not be comparable with those recorded here.

In our experiments caecal contents had greater proteolytic activity than rumen contents. The $\mathrm{pH}$ optimum for proteolysis in caecal liquor was higher than that in rumen liquor but was similar to that of trypsin ( $\mathrm{pH} 7 \cdot 6-8 \cdot 0$; Long, I961). Sym (1938), from similar observations on $\mathrm{pH}$ optima, suggested that trypsin was the main proteolytic enzyme in the caecum of the horse, whereas proteolytic enzymes in the rumen of cattle were of bacterial origin. Soluble proteolytic enzymes were present in caecal and faecal liquors but not in rumen liquor and could have accounted for part of the difference in proteolytic activity between rumen and large intestinal contents. Even so, the activities of enzymes associated with particulate matter in caecal contents were much greater than those of enzymes in whole rumen contents, suggesting that much of the difference was due to differences in microflora.

Most comparisons of the activities were made in relation to the wet weight of the contents or liquor. Comparison of rumen and caecal contents on a dry-weight basis would not have produced different results since whole contents from the rumen and caecum of slaughtered sheep had mean dry-matter contents of 10.4 and $10.1 \%$ respectively. Comparisons between the activities of caecal contents and faeces would have influenced the results as the average value for faecal dry matter was $28.4 \%$. Activities in faeces were approximately $2, I^{\cdot} \cdot 5$ and 4 times those of caecal contents for proteolysis, deaminase and urease activities respectively. These differences may reflect to some extent water absorption from the contents during their passage between the caecum and the rectum. The fact that ammonia and gas production in faeces was much less than in caecal contents indicates that little of the substrates necessary for these processes was present in faeces.

Another basis for comparison that might be considered is the number of microorganisms present. Brüggemann \& Giesecke ( 1963$)$ found by a direct counting method that the total count of micro-organisms in caecal contents of cattle was approximately twice that in rumen contents. Total counts have limited value as they do not distinguish the number of organisms that are metabolically active from dead residues. An attempt was made in these experiments to count micro-organisms by the method used by Moir (I95 I) for rumen contents but the results have not been presented since the large amount of debris in the large intestinal contents made counting in these contents difficult.

These experiments have shown that there was a continuous production of ammonia in caecal contents incubated in vitro and that much of it was derived from amino acids. This ammonia production and the low concentration of free $\alpha$-amino nitrogen in caecal liquor suggests that breakdown of proteins occurred. The identity of these 
proteins is not known although mucins were probably among the components. The decreased rate of production of ammonia in faeces implies that much of the potentially hydrolysable protein in caecal contents was degraded before the contents reached the rectum. This would give the large intestine the role of a 'scavenger' organ in which nitrogenous compounds, which escape hydrolytic digestion in the small intestine, enter the large intestine and are exposed to the action of a wider spectrum of enzymes produced by the microflora. The soluble products of this fermentation, mainly volatile fatty acids and ammonia, are absorbed and the ammonia is converted into urea in the liver and is then available for recycling to the rumen.

This work was carried out during the tenure of an Australian Meat Research Committee Senior Post-Graduate Studentship. I thank Professor A. T. Phillipson for his advice and criticism.

\section{REFERENCES}

Baker, F. (1939). Sci. Prog., Lond. r34, 287.

Begović, S. \& Pavlić, S. (1967). Veterinaria, Saraj. 16, 493 (quoted in Nutr. Abstr. Rev. (1968) 38, 802, Abstr. 47II).

Blackburn, T. H. \& Hobson, P. N. (1960). J. gen. Microbiol. 22, 272.

Brüggemann, J. \& Giesecke, D. (1963). Z. Tierphysiol. Tierernähr. Futtermittelk. 18, 215.

Conway, E. J. (1957). Microdiffusion Analysis and Volumetric Error. London: Crosby Lockwood \& Sons Ltd.

Erwin, E. S., Marco, G. J. \& Emery, E. M. (r96r). J. Dairy Sci. 44, 1768.

Grosskopf, J. F. W. (1964). Onderstepoort f. vet. Res. 31, 69.

Hungate, R. E., Phillips, G. D., Hungate, D. P. \& MacGregor, A. (1960). F. agric. Sci., Camb. 54, 196.

Hungate, R. E., Phillips, G. D., McGregor, A., Hungate, D. P. \& Buechner, H. K. (1959). Science, N.Y. I30, II92.

Long, C. (I96r). Biochemists' Handbook. London: E. \& F. N. Spon Ltd.

Moir, R. J. (1951). Aust. F. agric. Res. 2, 322.

Peters, J. P. \& Van Slyke, D. D. (1932). Quantitative Clinical Chemistry Vol. 2 Methods. London: Baillière, Tindall \& Cox.

Phillipson, A. T. (1964). In Mammalian Protein Metabolism Vol. I, p. 7 I [H. N. Munro and J. B. Allison editors]. New York and London: Academic Press.

Reinhold, J. G. (1953). In Standard Methods of Clinical Chemistry p. 88 [M. Reiner, editor]. New York: Academic Press Inc.

Spravcev, N. H. O. (1963). Zhivotnovodstvo 7, 82 (quoted in Nutr. Abstr. Rev. (1964) 34, 249).

Sym, E. A. (1938). Acta Biol. exp., Vars. 12, 192.

Umbreit, W. W., Burris, R. H. \& Stauffer, J. F. (195 I). Manometric Techniques and Tissue Metabolism and ed. Minneapolis: Burgess Publishing Co.

Warner, A. C. I. (1956). F. gen. Microbiol. 14, 749.

Warner, A. C. I. (1962). F. gen. Microbiol. 28, 119. 